\title{
The Antibacterial Activities of Lavandula stoechas and Crepis sancta Leaf and Flower Against Mastitis Pathogens and Enzymatic and Non- Enzymatic Antioxidant Activities of The Extracts
}

\author{
Nuray Ergün 1*, Gülten Ökmen², Pınar Erdal' ${ }^{2}$, Zafer Cantekin ${ }^{3}$, Yaşar Ergün ${ }^{4}$ \\ ${ }^{1}$ Department of Biology, Faculty of Science and Arts, Mustafa Kemal University, 31000 Hatay, Turkey \\ ${ }^{2}$ Department of Biology, Faculty of Science and Arts, Muğla Sitkı Koçman University, 48000 Muğla-Turkey \\ ${ }^{3}$ Department of Microbiology, Faculty of Veterinary Medicine, Mustafa Kemal University, 31000 Hatay, Turkey \\ ${ }^{4}$ Department of Obstetrics and Gynecology, Faculty of Veterinary Medicine, Mustafa Kemal University, 31000 Hatay, Turkey
}

\begin{tabular}{l}
\hline A R T I C L E I N F O \\
Research Article \\
Received 14 November 2017 \\
Accepted 01 March 2018 \\
\hline
\end{tabular}

Keywords:

Crepis sancta

Lavandula stoechas

Antibacterial activity

Antioxidant activity

Mastitis pathogens

\begin{tabular}{l} 
*Corresponding Author: \\
\hline E-mail: ergun.nuray@gmail.com
\end{tabular}

\begin{abstract}
A B S T R A C T
The antibacterial and antioxidant activities of Lavandula stoechas and Crepis sancta extracts on subclinical mastitis bacteria in cows have not been reported to the present day. The aim of this work was to investigate of the antibacterial and antioxidant potential of methanol extract from L. stoechas and C. sancta. Methanol extracts were screened for antibacterial activity against mastitis pathogens. The antibacterial activity was tested using disc diffusion and broth dilution method. In addition, the plant extracts were tested against the stable DPPH (1,1-Diphenyl-2-picrylhydrazyl) free-radical. Additionally methanol extracts were screened for enzymatic antioxidant activity. The methanol extract of C. sancta showed maximum inhibition zone against S. aureus-18 (16 mm). MIC (minimum inhibition concentration) value was determined as $3250 \mu \mathrm{g} / \mathrm{mL}$ for test bacteria. The highest radical scavenging capacity (62\%) was obtained from the flower extracts of L. stoechas and the leaf extracts of C. sancta. The methanol extract of C. sancta displayed a strong antioxidant activity (trolox equivalent $=1.6 \mathrm{mM} / \mathrm{g}$ ). It was determined that the activities of catalase (CAT) and ascorbate peroxidase (AP) enzymes were higher at the flowers of L. stoechas compared to the leaves. The extracts of L. stoechas and C. sancta leaf and flower have antibacterial and antioxidant potential against subclinic mastitis causative agent Staphylococci species.
\end{abstract}

DOI: https://doi.org/10.24925/turjaf.v6i5.543-549.1692

\section{Introduction}

Milk is a perfect bacteriological media for many microorganisms. When milked under hygienic conditions from a healthy cow, milk contains only a limited number of microorganisms present in the mammary duct. Sources of contamination can be the environment, milking equipments and the milker itself (Seguin et al., 1999; Khan et al., 2000). The most common microorganisms that cause mastitis are Staphylococcus, Streptococcus and coliform bacteria (Morin et al., 1998). Mastitis is the inflammatory reaction of the mammary gland tissue against several agents. Having been reported for years as the most common one among the bacterial agents of mastitis, Staphylococcus aureus still maintains this position (Karahan et al., 2009). S. aureus creates the normal flora of the skin and the mucous membrane (Mahon and Larsen 1995). As for the coagulase-negative staphylococci, which in the past were isolated from mastitis at a lower frequency, have been more commonly isolated from mastitis in the recent years and its prominence among the causes of disease gradually increases (Huxley et al., 2002; Taponen et al., 2006). Despite the fact that in subclinical mastitis infectious agents occur on the mammary gland and inflammatory changes take place in milk, no clinical changes take place on mammary gland or in milk. Diagnosis of this type of mastitis can only be made through some special tests (Rajala-Schultz et al., 2004). While clinical mastitis is observed in the form of sporadic cases, in the case of subclinical mastitis since the cows continue to spread the infection, the disease may infect other animals in the herd (Mustafa et al., 2011).

Mastitis is a frequently observed disease in dairy cattle and causes the highest economic loss in the dairy cattle breeding industry. It is reported that worldwide annual loss caused by mastitis is 35 billion dollars (Watts, 1988; Bramley, 1996; Wellenberg et al., 2002). 
In the treatment of the disease, antibiotics are widely used. Long-term use of antibiotics resulted in the development of strains resistant to multiple antibiotics, which in turn caused the use of increased doses of antibiotics and therefore antibiotic residue in milk. Eventually, a potential bio threat has risen (Dhanabalan et al., 2008). Mastitis cases caused by antibiotic-resistant $S$. aureus progress in a severe way and through the contaminated milk, resistant bacteria may infect the environment, other cows in a herd, and also humans through direct contact or via the food chain (Turutoglu et al., 2009). Due to this reason, today's scientists search for discovering and using new antibiotics against the bacteria that developed multiple antibiotic resistances.

As compounds that have high activity, free radicals originate from endogenous sources during the vital activities such as respiration, enzyme and auto oxidation reactions and from ambient sources such as cigarette smoke, air pollution, UV rays, ionized radiation and xenobiotics (Young and Woodside, 2001). Antioxidants are molecules that prevent the oxidation caused by free radicals, and that are able to interact with and stabilize free radicals. Depending on their sources, antioxidants are divided into two groups as artificial and natural antioxidants (Serteser and Gök, 2003). Natural antioxidants are present in nearly all plants, microorganisms and some animal tissues (Can et al., 2005). By developing varying types of antioxidants, plants have developed protection systems against the damages of the active oxygen forms caused by several stresses. By this means, with the help of antioxidant enzymes (catalase and ascorbate peroxidase), radicalscavenging compounds (caratenoids, ascorbic acid) and the other synthesized components, plants repair their cells and genetic materials (Mishra et al., 2005; Amira et al., 2012).

Turkey is rich in terms of endemic plants and covers the natural habitat of 10500 taxa, of which 3500 are endemic only in Turkey (Kaya and Raynal, 2001). The flora of the Amanos Mountains was identified with 91 family, 419 genera and 880 species (Akman, 1973). Considering that Turkey's flora has 1251 genera, (Davis, 1965-1988; Güner et al., 2000) it is understood that Amanos Mountains contain half of the plant genera available in Turkey. Within this floristic diversity, the endemism rate in the region is around 10\% (Yolcu, 2005).

Included in the Lamiacaea family, Lavandula stoechas is a perennial plant. The Lavandula stoechas subsp. stoechas subspecies of lavender grows naturally in the city of Hatay between the elevations of 100 and 700 meters. The species that is common in the Mediterranean Region is a $45-50 \mathrm{~cm}$ tall, pilous, strong scented and bushy plant. The most distinctive characteristics of this plant are its $0.5-2.5 \mathrm{~cm}$ pedicel and has a thickset plant form (Akman, 1973; Baytop, 1984). The volatile oil obtained from its leaves is used for treating headache, sleep withdrawal, burn injuries and as an expectorant. Other than these, it is also utilized in the cosmetics industry (Baytop, 2000) and as an ornamental plant.

Crepis sancta belongs to the Asteraceae family and its flowers are used in treating eye diseases, while its aboveground parts are used as feedstuff. Its tea is used for dilating blood vessels (Gençay, 2007), and its fresh leaves are used in salads (Ertuğ, 2004; Türkoğlu, 2000). Fleurentin et al.(1986) reported in their study that Crepis rueppellii (Sch.) Bip. ethanol extracts exhibit hepatoprotective effect against $\mathrm{CCl}_{4}$. In their study, Cakilcioglu et al. (2007) reported vasodilating properties of Crepis alpina L.

Although the literature includes studies on Lavandula stoechas, no study conducted for Crepis sancta could be found. No study concerning the antioxidant capacities and the antibacterial activity against pathogen bacteria and particularly against the agents of mastitis of the two edible medical herbs used in the present study could be found. The purpose of the present study is to examine the antibacterial activity of the leaf and flower extracts of Lavandula stoechas and Crepis sancta on coagulase negative Staphylococcus and S. aureus isolated from subclinical cow mastitis, and to determine the enzymatic and non-enzymatic antioxidant activities of the flower and leaf extracts of the two plants.

\section{Materials and Methods}

\section{Plant Material}

The study material plant samples of Lavandula stoechas and Crepis sancta were collected in April 2013, from various localities on the Amanos Mountains in Hatay. Plant materials were identified by Dr. Hikmet Yolcu and kept in the Turkey herbarium of Mustafa Kemal University Department of Biology. Identification of plant materials was carried out according to Davis (1965-1988).

\section{Microorganisms}

A total of 7 microorganisms sources among mastitis agents were used in the study, out of which two were $S$. aureus and the remaining five were CNS (coagulase negative Staphylococcus). All mastitis agents were isolated by Dr. Zafer Cantekin in a previously conducted project study (Project no: 1101 M 0103; Ethical Committee no: 2010/02-30:12). Identifications of all mastitis pathogens were carried out by using biochemical tests with classic culture methods (Quinn et al. 1994).

\section{Preparation of Plant Materials}

The flower and leaf components of the plants to be used in antibacterial activities and radical scavenging studies were washed a couple of times in streaming water and once in sterilized and distilled water. The flowers and leaves of the fresh plants were air dried and later pulverized in a mill. Until the preparation of samples, all materials were stored at room temperature, and then kept until needed for analyses at $4^{\circ} \mathrm{C}$. The leaves and flowers of the plants to be used in antioxidant enzyme activity studies, on the other hand, were kept fresh in a freezer ($20^{\circ} \mathrm{C}$ ) until needed for analyses.

\section{Preparation of Plant Extracts}

Air dried and pulverized plant samples were extracted through the use of methanol and soxhlet apparatus. After volatilizing the extracts, each of them was kept in methanol in small sterile opaque bottles under refrigerated conditions. Concentrations of all extracts were arranged as $100 \mathrm{mg} / \mathrm{mL}$. 


\section{Cultivation}

Mastitis agents were obtained from the previous study of Dr. Zafer Cantekin. Plant leaf and flower extracts were tested against mastitis agents. The bacteria used in the study were cultured by 24 hours incubation in Mueller Hinton Broth (MHB, Merck) medium at $37^{\circ} \mathrm{C}$. In all tests, 18 hour old active cultures were utilized and the turbidity of all bacterial cultures was arranged as per 0.5 McFarland.

\section{Determination of In Vitro Antibacterial Activity}

Antibacterial activity studies were conducted with the use of the Bauer-Kirby disc diffusion method. Methanol extracts of plant flowers and leaves $(100 \mathrm{mg} / \mathrm{mL})$ were tested with disc diffusion method. Test bacteria were incubated on Mueller - Hinton Agar plates (MHA, Merck) at $37^{\circ} \mathrm{C}$ for 24 hours. The turbidity of the mastitis agent bacteria cultures were arranged according to 0.5 McFarland. The inhibition zones generated after incubation were measured in $\mathrm{mm}$. Within the scope of the tests, methanol was tested as the negative control, while standard antibiotic disk (ampicillin, $10 \mu \mathrm{g}$ ) was tested as the positive control (Bauer et al. 1994). All tests were carried out in three repetitions.

\section{Minimum Inhibitory Concentration (MIC)}

Another antibacterial activity test conducted within the scope of the study is the determination of the minimum inhibition concentration (MIC) values. Broth dilution method was tried as it is defined in CLSI standards (CLSI, 2003; CLSI, 2006). MIC values of all flower and leaf extracts were recorded and reported as the lowest concentration that inhibits the post-incubation growth. The final concentrations of each extract were carried out to be $6500,3250,1625,812.5$ and 406.2 $\mu \mathrm{g} / \mathrm{mL}$.

Determination of Enzymatic and Non-Enzymatic Antioxidant Activities

In the non-enzymatic antioxidant activity studies, DPPH was used as free radical. The extract $(0.1 \mathrm{~mL})$ used in the tests, was added to $0.1 \mathrm{mM}$ methanolic DPPH solution $3.9 \mathrm{~mL}$. After 30 minutes of incubation, the absorbance of the extract was detected at $515 \mathrm{~nm}$ by using spectrophotometer. While the methanolic DPPH was used as the control (Brand-Williams et al. 1995), trolox was used as the standard antioxidant. DPPH radical scavenging activity (\%) was determined in line with the following formula.

$$
\mathrm{DPPH}=[\text { Abs }(\text { control })-\text { Abs }(\text { extract })] \times 100
$$

Within the scope of the enzymatic antioxidant studies, antioxidant enzyme activities were determined in the flowers and leaves of the fresh plants. In this study ascorbate peroxidase and catalase enzyme activities were tested. Ascorbate peroxidase (AP, E.C. 1.11.1.11) activity was determined by measuring ascorbate oxidation rate in $290 \mathrm{~nm}$ according to Cakmak and Marschner (1992) and Cakmak (1994). Catalase enzyme activity (CAT, E.C. 1.11.6.1) on the other hand was measured with a spectrophotometer as per the decomposition rate of $\mathrm{H}_{2} \mathrm{O}_{2}$ at $240 \mathrm{~nm}$ (Cakmak and Marschner, 1992). AP and CAT enzyme activities were calculated and recorded in terms of $(\mu \mathrm{M} / \mathrm{min} / \mathrm{g} \mathrm{F} . \mathrm{W})$ and fresh weight. All tests were conducted simultaneously with three repetitions and the obtained results were expressed as averages.

\section{Results}

Antibacterial activities of the methanol extracts of the leaves and flowers of Lavandula stoechas and Crepis sancta were tested on $S$. aureus isolated from subclinical cow mastitis. Antibacterial activities of methanol extracts belonging to the separate components of the two plants used against the test bacteria, and the inhibition zone diameters of the reference antibiotic are summarized in Table 1.

Data obtained as a result of the study show that methanol extracts belong to leaves and flowers of Lavandula stoechas and Crepis sancta have antibacterial activity on mastitis pathogens. While extracts of both plants have antibacterial activity on all test bacteria, no activity was determined only on $S$. aureus-18. When antibacterial effects of leaves and flowers extracts on $S$. aureus and CNS species are compared, the highest activity from leaf extract of $C$. sancta on $S$. aureus-18 was determined as $(16 \mathrm{~mm})$ and the lowest activity was found on CNS-32 as $10 \mathrm{~mm}$. While leaf extract of C. sancta shows high activity against both $S$. aureus, antibacterial activity shown against CNS is found to be partially lower. While $C$. sancta shows high inhibition effect against the development of all test bacteria, both extract of $L$. stoechas do not show inhibition effect against only $S$. aureus-18. Further, antibacterial effects of leaves and flowers of L. stoechas are found to be lower comparing with $C$. sancta. In addition, in the values of extracts of different parts of L. stoeachas close to each other are determined to have antibacterial effect. While both extract of L. stoechas show the highest activity against CNS-36 $(13 \mathrm{~mm})$, the lowest antibacterial activity from leaf extract against CNS-22 was determined as $8 \mathrm{~mm}$ (Table 1).

Table 1 The antibacterial activities of Lavandula stoechas and Crepis santa against mastitis pathogens

\begin{tabular}{l|cccc}
\hline \multirow{2}{*}{ Bacteria } & \multicolumn{4}{|c}{ Inhibition zone diameter (mm) } \\
\cline { 2 - 5 } & Lavandula stoechas (leaf) & Lavandula stoechas (flower) & Crepis sancta (leaf) & Antibiotic \\
\cline { 2 - 5 } S. aureus- 17 & 9 & 10 & 15 & 18 \\
S. aureus- 18 & - & - & 16 & 12 \\
CNS- 22 & 8 & 9 & 12 & - \\
CNS- 32 & 9 & 9 & 10 & 10 \\
CNS- 33 & 9 & 9 & 12 & 8 \\
CNS- 36 & 13 & 13 & 12 & - \\
CNS- 37 & 10 & 11 & & - \\
\hline
\end{tabular}


Table 2 MIC values of Lavandula stoechas and Crepis sancta extracts

\begin{tabular}{l|ccc}
\hline \multirow{2}{*}{ Bacteria } & \multicolumn{3}{c}{ Plant extracts $(\mu \mathrm{g} / \mathrm{mL})$} \\
\cline { 2 - 4 } & Lavandula stoechas (leaf) & Lavandula stoechas (flower) & Crepis sancta (leaf) \\
\hline S. aureus- 17 & 6500 & 3250 & 6500 \\
S. aureus- 18 & 3250 & 3250 & 6500 \\
CNS - 22 & 3250 & 3250 & 6500 \\
CNS - 32 & 6500 & 3250 & 6500 \\
CNS - 33 & 3250 & 3250 & 3250 \\
CNS - 36 & 3250 & 3250 & 3250 \\
CNS - 37 & 3250 & 3250 & 6500 \\
\hline
\end{tabular}

CNS: coagulase negative staphylococci

Table 3 Enzymatic and non-enzymatic antioxidant activities of L. stoechas and C. sancta extracts

\begin{tabular}{l|ccc}
\hline \multirow{2}{*}{ Antioxidant activity } & \multicolumn{3}{|c}{ Plant extracts $(100 \mathrm{mg} / \mathrm{mL})$} \\
\cline { 2 - 4 } & Lavandula stoechas (leaf) & Lavandula stoechas (flower) & Crepis sancta (leaf) \\
\hline DPPH $(\%)$ & 42 & 62 & 62 \\
TE $(\mathrm{mM} / \mathrm{g})$ & 1.1 & 1.6 & 1.6 \\
$\mathrm{CAT}(\mu \mathrm{M} / \mathrm{min} / \mathrm{g} \mathrm{FW})$ & $0.33 \pm 0.02$ & $0.47 \pm 0.03$ & $0.88 \pm 0.04$ \\
$\mathrm{AP}(\mu \mathrm{M} / \mathrm{min} / \mathrm{g} \mathrm{FW})$ & $6.86 \pm 0.26$ & $8.55 \pm 0.11$ & $9.29 \pm 0.26$ \\
\hline
\end{tabular}

CAT: Catalase activity AP: Ascorbate peroxidase TE: Trolox equivalent FW: fresh weight

Antibacterial activity studies have been tested against mastitis pathogens by using broth dilution method. In Table 2, MIC values of methanol extracts belong to leaves and flowers of Lavandula stoechas and Crepis were summarized. While all of flower extracts of L. stoechas shows $3250 \mu \mathrm{g} / \mathrm{mL}$ MIC value, different MIC values were determined in leaf extracts of both plants (Table 2).

Non-enzymatic antioxidant activities of the leaf and flower methanol extracts of Lavandula stoechas and Crepis sancta $(100 \mathrm{mg} / \mathrm{mL})$ were determined by means of the DPPH radical scavenging capacity. Antioxidant activities of the methanol extracts belonging to $L$. stoechas and $C$. sancta are summarized in Table 3. DPPH radical scavenging capacity was determined by using trolox as the reference antioxidant, and the data obtained from the study were recorded on the basis of trolox equivalents. Within the scope of the study, the highest radical scavenging capacity $(62 \%)$ was obtained from the flower extracts of $L$. stoechas and the leaf extracts of $C$. sancta, while the lowest radical scavenging capacity (42 $\%$ ) was obtained from L. stoechas leaf extract. Similarly, also the trolox equivalents of the methanol extracts exhibited different values, and the highest trolox equivalent value of $1.6 \mathrm{mM} / \mathrm{g}$ was obtained from the same aboveground parts (Table 3 ).

In the study, antioxidant enzyme activities of the fresh leaves and flowers of Lavandula stoechas and Crepis sancta were determined. In enzymatic antioxidant activity studies, ascorbate peroxidase and catalase enzyme activities were tested. According to the results of the study, it was determined that when considering the aboveground parts of $L$. stoechas, both antioxidant enzyme activities are high in the flower component. While the catalase activity in L. stoechas flower was determined to be $0.47 \mu \mathrm{M} / \mathrm{min} / \mathrm{gF}$.W, ascorbate activity was determined to be $8.55 \mu \mathrm{M} / \mathrm{min} / \mathrm{gF}$.W. However, the enzymatic antioxidant activities of the leaves of $L$. stoechas were found out to be lower than that of the flowers.
As for the enzymatic activities of the leaves of Crepis sancta, they were determined to be higher than that in the other components of the plant. The highest enzyme activity was obtained from the ascorbate peroxidase enzyme activity in the leaves of $C$. sancta $(9.29$ $\mu \mathrm{M} / \mathrm{min} / \mathrm{gF} . \mathrm{W})$ (Table 3).

\section{Discussion and Conclusion}

Mastitis is a disease that results in heavy economic losses such as $70 \%$ from milk yield, 9\% from milk disposal after treatment, $7 \%$ from veterinary services cost and $14 \%$ from premature exclusion from herd (Bhikane and Kawitkar, 2000). Antimicrobial agents are used for treatment of mastitis during the milking period and for protection in the dry period. This approach is very important in terms of curative and prophylactic intervention. Due to the insensible consumption of antibiotics today, bacteria started to develop an ever strengthening resistance against antibiotics. Therefore, today's studies focus on the discovery of new medicines. World Health Organization reports that $74 \%$ of the medicines consumed from vegetal sources have a modern indicator and that their traditional and cultural uses are related though local cultures (Das Ayyappa and Doss, 2009).

Antibacterial activity analyses were conducted on 7 Staphylococci isolated from subclinical cow mastitis (2 S. aureus and $5 \mathrm{CNS}$ ). Leaf and flower methanol extracts belonging to Lavandula stoechas and $C$. sancta were found out to be effective against mastitis pathogens (Table 1).

The highest antibacterial activity in the study was obtained from $C$. sancta leaf extract against $S$. aureus-18 $(16 \mathrm{~mm})$ (Table 1). Similarly, in the study they conducted Ndom et al. (2006) reported that the compounds obtained from Crepis cameroonica had an effect that inhibited the development of $S$. aureus. On the other hand, in the study they conducted with Pilosella sandrasica, Ugur et al. (2009) reported antibacterial activity effective against $S$. aureus. These studies conducted in the recent years support our results. 
According to the findings of the present study, the antibacterial activity of the leaf and flower extracts belonging to L. stoechas was found out to be lower than the activity of $C$. sancta (Table 1). In the compilation conducted by Zidron (2008), it is reported that the different species of Crepis contain a high number of secondary metabolites, which are gathered under three groups as costus lactone type guaianolides, lactusine type guaianolides and hierasin type guaianolides. It is considered that this diversity among plant species may be due to the land differences and different types of vegetation.

In the study it was also determined that the extracts of different components of L. stoechas have similar levels of antibacterial activity (Table 1). In a study conducted with Lavandula stoechas L., it was reported that although the rate of essential oil varies in the flowers and leaves, the active compounds carried show similarity, and some of these compounds were similar to the essential oil of $L$. cariensis (Tanker et al., 1977). In this respect, it is considered that the similar antibacterial activities exhibited by different plant components are a natural result.

Minimum inhibitory concentration is defined as the minimum concentration of the antimicrobial substance that inhibits the visible growth of the microorganism after a whole night of incubation. Considering the data obtained from the study, the minimum inhibitory concentration of the extracts of different parts of $L$. stoechas and C. sancta was determined to be $3250 \mu \mathrm{g} / \mathrm{mL}$ (Table 2). Aligiannis et al. (2001), classified plant materials on the basis of MIC results and classified MIC values up to $500 \mu \mathrm{g} / \mathrm{mL}$ as strong inhibitor, the values between 600 and $1500 \mu \mathrm{g} / \mathrm{mL}$ as moderate inhibitor and values over $1600 \mu \mathrm{g} / \mathrm{mL}$ as weak inhibitor. According to this, the methanol extracts of $L$. stoechas are C. sancta accepted as weak inhibitor against mastitis pathogens.

In the non-enzymatic antioxidant activity analyses, the highest radical scavenging capacity was obtained from $L$. stoechas flower and C. sancta leaf extracts (62\%) (Table 3). While Orhan et al. (2012) reported 42\% DPPH radical scavenging activity in Crepis foetida L., Ferreira et al. (2006) reported $70 \%$ in Lavandula pedunculata, and Miliauskas et al. (2004) reported 35\% in Lavandula angustifolia. These results are similar to our own analyses. Other than this, in the phytochemical analyses conducted on Lavandula stoechas, it was determined that the aboveground parts of the plant contain glycoside and saponins (Baytop, 2000), oleanolic acid, ursolic acid, versatic acid, $\beta$-sitosterol, $\alpha$ - amyrin, $\alpha$-amyrin acetate and vitexin (Ulubelen and Olcay, 1989), longipin derivatives (Ulubelen et al., 1988; Upson et al., 2000 ), and molecules such as 7-methoxy coumarin and lavanol. In addition, it was reported to contain essential oil at the rates between $0.77-1.2 \%$, and fenchone, camphor, pinocarvyl acetate, eucalyptole and mirtenol as the main components (Gilani et al., 2000).

In the study, the antioxidant activities of the leaf and flower extracts of L. stoechas were found out to be different than each other (Table 3). Shahidi and Marian (2003) stated that the differences in the antioxidant activities of plant extracts can be due to the qualitative and quantitative compositions of the phenolic components. The composition of plant extracts and oils on the other hand were connected to the local climate and environmental conditions in several studies (Janssen et al., 1987; Sivropoulou et al., 1995). In the study Goren et al. (2002) conducted with L. stoechas ssp. stoechas, the authors reported that only the plant essential oil contains 42 separate components. This report also supports the results we obtained from out study.

According to the enzymatic antioxidant activity analyses, the activities of the leaves of Crepis sancta was found out to be higher than the enzyme activities of the leaves and flowers of $L$. stoechas. It was also determined that the catalase and ascorbate peroxidase activities of $L$. stoechas flowers were higher, despite the lower activities of the leaves (Table 3). It is stated that the phytochemicals available in plants may differ based on the conditions in which the plant grows and the genetic factors. It is also known that also the growth of the plant and even the hour when sampling was carried out may alter plant content (Öztürk et al., 2005). It is stated that under stress conditions such as salinity, aridity, flooding and heavy metals, antioxidant enzyme activity increases (Keleş and Öncel, 2002; Ergün and Öncel, 2012). It is known that the responses plants give against stress vary according to the species of the plant, its development, the habitat it grows and the duration of the stress it is exposed to.

According to the results obtained from the study, it was determined that L. stoechas and Crepis sancta extracts have high antibacterial activity against mastitis agents. In the conclusion of the study, it is determined that both of the plants exhibit high levels of activity and therefore can be considered as alternative antibiotic sources. In addition, it is needed to further examine the compounds of the essential oils and extracts of the medical herbs that are determined to have high antioxidant and antibacterial effects. On the other hand, it is also necessary to examine the reliability and toxicity problems of such compounds.

\section{Acknowledgement}

We are thankful to Dr. Hikmet Yolcu for plant identification.

\section{References}

Akman Y. 1973. Contribution a iètude de Flore des Montagnes de IÀmanus. I - III. Comm. Fac Sci Univ Ank., 17: 1-70.

Aligiannis N, Kalpotzakis E, Mitaku S, Chinou IB. 2001. Composition and antimicrobial activity of the essential oils of two Origanum species. J Agric Food Chem., 40: 41684170.

Amira S, Dade M, Schinella G, Ríos, JL. 2012. Antiinflammatory, antioxidant, and apoptotic activities of four plant species used in folk medicine in the Mediterranean basin. Pak J Pharm Sci., 25(1): 65-72.

Bauer AW, Kirby WM, Sheris JC, Turck M. 1966. Antibiotic susceptibility testing by a standardized single disc method. Am J Clin Pathol., 45: 149-158.

Baytop T. 1984. Türkiye' de Bitkiler ile Tedavi. İstanbul Üniversitesi Yayınları. İstanbul. No:3255. 520. (in Turkish).

Baytop T. 2000. Türkiye'de Bitkiler ile Tedavi-Geçmişte ve Bugün. Nobel Kitap Evi. İstanbul. p. 284-285. (in Turkish).

Bhikane AV, Kawitkar SB. 2000. Hand book for Veterinary Clinician. Venkatesh Books. Udgir, India. 
Bramley AJ. 1996. Current Concepts of Bovine Mastitis. The National Mastitis Council, Madison WI 53704.

Brand-Williams W, Cuvelier ME, Berset C. 1995. Use of a free radical method to evaluate antioxidant activity. Food Sci Technol., 28: 25-30.

Cakılcioglu U, Turkoglu I, Kursat M. 2007. Ethnobotanical features of Harput (Elazı $\breve{g}$ ) and its vicinity. J. Res. Eastern Anatolia Reg., 5: 22-28.

Çakmak I, Marschner H. 1992. Magnesium Defficiency and High-Light Intensity Enhance Activities of Superoxide Dismutase, Ascorbate Peroxidase and Glutathione Reductase in Bean Leaves. Plant Physiol., 98: 1222-1227.

Çakmak I. 1994. Activity of Ascorbate-Dependet $\mathrm{H}_{2} \mathrm{O}_{2}$ Scavenging Enzymes and Leaf Cholorosis are Enhanced in Magnesium- and Potassium- Deficient Leaves, But not in Phosphorus-Deficient Leaves. J Exp Bot. 45: 1259-1266.

Can A, Özçelik, B Güneş G. 2005. Meyve sebzelerin antioksidan kapasiteleri. GAP IV. Tarım Kongresi, Şanlıurfa, 21-23 Eylül. (in Turkish).

CLSI (Clinical and Laboratory Standards Institute). 2003. Methods for Dilution Antimicrobial Susceptibility Test for Bacteria that Grow Aerobically. Approved Standard M7-A 6th edn. Nat. Comm. Clinical. Lab. Standards, Wayne, Philadelphia.

CLSI (Clinical and Laboratory Standards Institute). 2006. Performance Standards for Antimicrobial Susceptibility Testing. $16^{\text {th }}$ Informational Supplement M100-S16. Nat. Comm. Clinical. Lab. Standards, Wayne, Philadelphia.

Das Ayyappa MP, Doss DR. 2009. A in vitro antibacterial activity of two medicinal plants against bovine udder isolated bacterial pathogens from dairy herds. Ethnobot Leaf., 13: 152-158.

Davis PH. 1965-1988. Flora of Turkey and the East Aegean Islands. I-X. Edinburg Unv. Press, Edinburg.

Dhanabalan R, Doss A, Jagadeeswari M, Balachandar S, Kezia E. 2008. In vitro phytochemical screening and antibacterial activity of aqueous and methanolic leaf extracts of Tridax procumbens against bovine mastitis isolated Staphylococcus aureus. Ethnobot Leaf., 12: 1090-1095.

Ergün N, Öncel I. 2012. Effects of some heavy metals and heavy metal hormone interactions on wheat (Triticum aestivum L. cv. Gun 91) seedlings. Afr J Agric Res., 7(10): 1518-1523.

Ertuğ F. 2004. Wild Edible Plants of Bodrum Area (Muğla, Turkey). Turk. J. Bot. 28: 161-174.

Ferreira A, Proenca C, Serralheiro MLM, Araujo MEM. 2006. The in vitro screening for acetylcholinesterase inhibition and antioxidant activity of medicinal plants from Portugal. J Ethnopharmacol., 108: 31-37.

Fleurentin J, Hoefler C, Lexa A, Mortier F, Pelt JM. 1986. Hepatoprotective properties of Crepis rueppellii and Anisotes trisulcus: two traditional medicinal plants of Yemen. J. Ethnopharmacol., 16(1): 105-111.

Gençay A. 2007. Cizre (Şırnak)'nin Etnobotanik Özellikleri. Yüzüncü Y1l Ünüversitesi Fen Bilimleri Enstitüsü. Yüksek Lisans Tezi. 248. (in Turkish).

Gilani AH, Aziz N, Khan MA, Shaheen F, Jabeen Q, Siddiqui BS, Herzig JW. 2000. Ethnopharmacological evaluation of the anticonvulsant, sedative and antispasmodic activities of Lavandula stoechas L. J Ethnopharmacol., 7: 161-167.

Gören AC, Topcu G, Bilsel G, Bilsel M, Aydogmus Z, Pezzuto JM. 2002. The Chemical Constituents and Biological Activity of Essential Oil of Lavandula stoechas ssp. stoechas. Verlag der Zeitschrift für Naturforschung, Tübingen. 797-800.

Güner A, Özhatay N, Ekim T, Başer KH. C. 2000. Flora of Turkey and East Eagen Islands (Supplement). Edinburgh Unv. Press, Edinburgh. Vol:11.

Huxley JN, Green MJ, Green LE, Bradley AJ. 2002. Evaluation of the efficacy of an internal teat sealer during the dry period. J Dairy Sci., 85: 551-561.
Janssen AM, Scheffer JJC, Baerheim Svendsen A. 1987. Antimicrobial activity of essential oils: a 1976-86 literature review. Aspects of the test methods. Planta Medica., 53: 395-398.

Karahan M, Açık MN, Çetinkaya B. 2009. Investigation of toxin genes by polymerase chain reaction in Staphylococcus aureus strains isolated from bovine mastitis. Foodborne Pathogens Dis., 6: 1-7.

Kaya Z, Raynal DJ. 2001. Biodiversity and Conservation of Turkish Forests. Biol Conserv., 97(2): 131-141.

Keleş Y, Öncel I. 2002. Response of antioxidative defence system to temperature and water stress combinations in wheat seedling. Plant Sci., 163(4): 783-790.

Khan SA, Nawaz MS, Khan AA, Cerniglia CE. 2000. Transfer of erythromycin resistance from poultry to human clinical strains of Staphylococcus aureus. J Clin Microbiol., 38: 1832-1838.

Mahon CR, Larsen HS. 1995. Staphylococcus aureus. In: Mahon, C. R. et al. (eds.). Textbook of Diagnostic Microbiology, W.B. Saunders Company, New York. 325330.

Miliauskas, G., Venskutonis, P. R., van Beek, T. A. 2004. Screening of radical scavenging activity of some medicinal and aromatic plant extracts. Food Chem. 85: 231-237.

Mishra J, Srivastava RK, Shukla SV Raghav CS. 2007. Antioxidants in aromatic and medicinal plants. Sci Tech. Entrepr., 7: 1-16.

Morin DE, Constable PD, McCoy GC. 1998. Use of clinical parameters for differentiation of Gram-positive and Gramnegative mastitis in dairy cows vaccinated against lipopolysaccharide core antigens. J Am Vet Med Assoc., 212: 1423-1431.

Mustafa YS, Awan FN, Zaman T, Chaudhry SR, Zoyfro V. 2011. Prevalence and Antibacterial Susceptibility in Mastitis in Buffalo and Cow in and Around The District LahorePakistan. Pak J Pharm., 24 (1-2): 29-33.

Ndom JC, Mbafor JT, Wansi JD, Kamdem AW, Meva'a LM, Vardamides JC, Toukam F, Pegyemb D, Ngando TM, Laatsch H, Fomum ZT. 2006. Sesquiterpene lactones from Crepis cameroonica (Asteraceae). Nat Prod Res., 5(20): 435-442.

Orhan DD, Ozcelik B, Hoşbaş S, Vural M. 2012. Assessment of antioxidant, antibacterial, antimycobacterial, and antifungal activities of some plants used as folk remedies in Turkey against dermatophytes and yeast-like fungi. Turk J Biol., 36: 672-686.

Öztürk B, Konyalıŏlu S, Kantarcı G, Çetinkol D. 2005. İzmir yöresindeki yabani Lavandula stoechas L. subsp. stoechas taksonundan elde edilen uçucu yağın bileşimi, antibakteriyel, antifungal ve antioksidan kapasitesi. Anadolu J AARI., 15(1): 61-72. (in Turkish).

Quinn PJ, Carter ME, Markey BK, Carter GR. 1994. Clinical Veterinary Microbiology. Mosby-Year Book Europe Limited. Lynton House, London WC1H9LB, England. 209236.

Rajala-Schultz PJ, Smith KL, Hogan JS, Love BC. 2004. Antimicrobial susceptibility of mastitis pathogens from first lactation and older cows. Vet Microbiol., 102: 33-42.

Seguin JC, Walker RD, Caron JP, Kloos WE, George CG, Hollis RJ, Jones RN, Pfaller MA. 1999. MethicillinResistant Staphylococcus aureus outbreak in a Veterinary Teaching Hospital: Potential human-to-animal transmission. J Clin Microbiol., 37: 1459-1463.

Serteser A. Gök V. 2003. Doğal Antioksidanların Biyoyararlılı̆̆ı. 3. Gıda Mühendisliği Kongresi, Ank. 2-4 Ekim. (in Turkish).

Shahidi F. Marian N. 2003. Phenolics in Food and Nutraceuticals, vol. 1, CRC Press, Boca Raton. 144-150.

Sivropoulou A, Kokkini S, Lanaras T., Arsenakis M. 1995. Antimicrobial activity of mint essential oils. J Agric Food Chem., 43: 2384-2388. 
Tanker N, Şarer E, Başaran V. 1977. Lavandula stoechas L. Bitkisinin Uçucu Yağı Üzerinde Farmakognozik Araştırmalar. Ank Ecz Fak Mec., 7: 61-66. (in Turkish).

Taponen S, Simojoki H, Haveri M, Larsen HD, Pyorala S. 2006. Clinical characteristics and persistence of bovine mastitis caused by different species of coagulase-negative staphylococci identified with API or AFLP. Vet Microbiol., 115: 199-207.

Türkoğlu İ. 2000. Elazığ İlindeki Etnobotanik Değeri Olan Taksonların Araştırılması. Fırat Üniversitesi, Fen Bilimleri Enstitüsü, Biyoloji Anabilim Dalı. Yüksek Lisans Tezi. (in Turkish).

Turutoglu H, Hasoksuz M, Ozturk D, Yildirim M, Sagnak S. 2009. Methicillin and aminoglycoside resistance in Staphylococcus aureus isolates from bovine mastitis and sequence analysis of their mecA genes. Vet Res Commun., 33: 945-956.

Ugur A, Okmen G, Sarac N, Ceylan O, Duru ME, Varol O. 2009. Antimicrobial activity and chemical composition of Pilosella sandrasica on endemic species to Turkey. Acta Horticulturae, Number 853. Proceedings of the International Symposium on Medicinal and Aromatic Plants. SIPAM Neffati, M. et al. (eds). ISHS, Belgium. 329-335.
Ulubelen A, Goren N, Olcay Y. 1988. Longipinen derivatives from Lavandula stoechas. Phytochem. 27: 3966-3967.

Ulubelen A, Olcay Y. 1989. Triterpenoids from Lavandula stoechas. Fitoterapia. 60: 475, 476.

Upson TM, Grayer RJ, Greenham JR, Williams CA, AlGhamdi F, Chen F. 2000. Leaf flavonoids as systematic characters in the genera Lavandula and Sabaudia. Biochem Syst Ecol., 28: 991-1007.

Watts JL. 1988. Etiological agents of bovine mastitis. Vet Microbiol., 16: 41-66.

Wellenberg GL, Van der Poel WHM, Van Orschot JT. 2002. Viral infections and bovine mastitis: a review. Vet Microbiol., 88: 27-45.

Yolcu H. 2005. Kızıldağ (Hatay) Vejetasyonunun Araştırılması. Doktora Tezi. Çukurova Üniv. Fen Bil. Enstitüsü. Adana. (in Turkish).

Young IS. Woodside JV. 2001. Antioxidants in Health and Disease. J Clin Pathol., 54: 176-186.

Zidorn C. 2008. Sesquiterpene lactones and their precursors as chemosystematic markers in the tribe Cichorieae of the Asteraceae. Phytochem. 69: 2270-2296. 